\title{
下咽頭癌に対する下咽頭喉頭頸部食道全摘と遊離空腸による再建
}

$$
\begin{aligned}
& \text { 森 一功1) - 平野 実1) - 柏木 彰一1) - 矢武 克之 }{ }^{1)} \\
& \text { 田井 良明2) - 清川 兼輔 } 2) \text { - 藤田 博正 }{ }^{3)} \text {. 早㴊 尚文 }{ }^{4)}
\end{aligned}
$$

\section{Pharyngolaryngectomy and Esophagotomy with Jejunum Transplantation for Hypopharyngeal Carcinoma}

\author{
Kazunori Mori, Minoru Hirano, Shoichi Kashiwagi, Katsuyuki Yatake, \\ Yoshiaki Tai, Kensuke Kiyokawa, Hiromasa Fujita and Naofumi Hayabuchi \\ (School of Medicine, Kurume University)
}

\begin{abstract}
Pharyngolaryngectomy and esophagotomy with bilateral extended radical neck dissection and upper mediastinal dissection combined with free jejunum transplantation was performed for fortytwo patients with hypopharyngeal carcinoma. The three-year survival rate as determined by the Kaplan-Meier method was 58.9\%. Survival rate of patients with neck metastasis was better than that of patients without neck metastasis. Patients who underwent post-operative irradiation showed a better survival rate than patients without irradiation. As for complications, $12 \%$ of patients showed fistula-formation, $12 \%$ showed abscess-formation around the tracheostoma, $7 \%$ died from surgery and complications, and $5 \%$ showed total necrosis of the transplanted jejunum.

Stenosis around the anastomosis tended to decrease over time. These results suggest that this surgical method is effectively increased the survival rate for hypopharyngeal carcinoma, although further improvement is necessary to reduce the rate of distant metastasis and lymph node recurrence.
\end{abstract}

Key words : hypopharyngeal carcinoma, jejunum transplantation, extended radical neck dissection

\section{緒言}

下咽頭癌は周知の通り, 頭頸部領域の癌のらち治療成 績の悪いものの一つである．当院では1989年来，耳鼻咽 喉科, 形成外科, 消化器外科(以下, 外科), 放射線科か らなる治療チームを結成し，下咽頭癌の治療を行なって きた．これは，上縦隔リンパ節やルビェール・リンパ節 を含めて広範囲に両側の頸部郭清を行ない,ささら上咽 頭と縦隔への術後照射を行ならことでリンパ節再発を抑 え,十分な安全域をつけた下咽頭喉頭頸部食道摘出術(以 下，咽喉食摘）を行ならことで原発巣再発を抑えようと
いらものである。また，術後照射を可及的早く開始でき ること，患者の経口摂取を早く開始できることから，切 除後の咽頭の再建には遊離空腸移植を行なっている.

本研究では1989年から1994年 4 月までに咽喉食摘と遊 離空腸による一期的再建を行なった 42 症例について，本 治療方法の術後の経過について検討した。すなわち, TNM 別, 術後照射の有無別, 胸部食道癌合併の有無別 等に生存率を計算し，それらが手術結果にどら影響して いるかを知ろらとした。ついで死因や合併症を分析して 本法の反省点や今後の対策を知る手がかりを得ようと試
1）久留米大学医学部耳鼻咽喉科学教室

3）久留米大学医学部第一外科学教室
2) 久留米大学医学部形成外科学教室

4) 久留米大学医学部放射線科学教室 
みた。

\section{治療方法}

治療方法はおおむむね以下の如くである。

まず，術前に頭蓋底から気管分枝部までの CT をとっ て，ルビェール・リンパ節と縦隔リンパ節の腫大の有無 も含めて，原発巣と転移の範囲を調べて扣く。また，食 道の精查を行ない，食道癌の有無を調べておく．

手術は耳鼻咽喉科が両側頸部郭清と咽喉食摘を行なら。 この際, 甲状腺も全摘出し, 傍気管リンパ節, 上縦隔も 郭清する. 空腸移植のために, 通常, 頸横動脈と外頸静 脈とを保存する，咽喉食摘に際しては，上方は腫瘍上限 から最低 $2 \mathrm{~cm}$ 上方，多くは口蓋扁桃上極付近で，下方 は腫瘍下限から最低 $2.5 \mathrm{~cm}$ 下方で切除する。 その後, ルビェール・リンパ節の触診を十分行ない，腫脹が認め られれば摘出する．次いで外科が開腹して空腸を摘出す る. 食道癌を合併していない場合，摘出した空腸を形成 外科が血管吻合し，外科と形成外科とが下咽頭を再建す る. 食道癌を合併していても粘膜内癌の場合には同様の 方法で咽頭を再建し, 粘膜内癌に対しては後日レーザー で焼灼する，食道癌を合併していて，粘膜下に進展して いる場合には，外科が食道を抜去し，胃管を形成して釣 り上げ，胃管上端と中咽頭の切除断端との間を，形成外 科と外科とが遊離空腸を用いてつなぐ。この際, 縦隔リ ンパ節の腫脹があれば外科が郭清する。

術直後の全身管理は，胃管釣り上げを行なった場合は 外科が，行なわない場合は耳鼻咽喉科が行なう。

術創が治癒した後，放射線科がルビェール・リンパ節 と上綎隔に基準総線量ほぼ $60 \mathrm{~Gy}$ の照射を行なら。ま た，頸部リンパ節に転移があり，リンパ節の被膜外浸潤 があれば頸部にも照射する。食道粘膜内癌がある場合は， この照射中に外科が内視鏡下にレーザーで焼灼する.

術後の follow-up は耳鼻咽喉科, 外科, 放射線科が共 同して行なら．また，吻合部に狭窄が生じたときは外科 がブジーを行なう。

\section{対象と方法}

対象は1989年から1994年 4 月までの間に久留米大学医 学部耳鼻咽喉科に和いて咽喉食摘と遊離空腸による一期 的再建を行なった下咽頭癌初治療例42名 (男性38名, 女 性 4 名, 31 83歳, 平均63歳)である.

部位別では，輪状後部が 5 名，梨状陥凹が 31 名，咽頭
後壁が 6 名であった（表 1 )。TNM 別では T2 が 9 名， T3 が18名, T4 が15名で, T1 症例はなかった。また N0, N1，N2，N3 がそれぞれ 9 名，8名，22名，3名であ った(表 2)。また，全例 $\mathrm{M} 0$ で，M1 症例はいなかった。 再建方法は遊離空腸のみが36名, 胃管釣り上げ+遊離 空腸が 6 名であった．胸部食道癌合併例は全部で 9 名あ り， 3 例は術後のレーザー焼灼を行ない，6 例は食道抜 去で処理された(表 3 ).

放射線治療は31例に行ない，そのうち30例では術後照 射を，1例では術前照射を行なった．11例で術後放射線 治療を行なわなかった理由は，放射線治療前に死亡が 3 例，治療拒否が 1 例，肺結核の排菌陽性が 1 例，肺転移 が見つかったためが 2 例で，体力の回復を待ってからと いら本人家族の要望により退院し，その後照射を拒否し たものが 4 例である。

この対象について以下の検討を行なった.

1 ) 生存率の算出

生存率は他病死例を打ち切りとしてカプラン・マイ ヤー法を用いて $1 \sim 3$ 年生存率を計算した.

表 1 部位別症例数

\begin{tabular}{l||r|r|r}
\hline \hline & 男性 & 女性 & 計 \\
\hline 輪状後部 & 4 & 1 & 5 \\
\hline 梨状陥凹 & 29 & 2 & 31 \\
\hline 咽頭後壁 & 5 & 1 & 6 \\
\hline 計 & 38 & 4 & 42
\end{tabular}

表 $2 \mathrm{TN}$ 別症例数

\begin{tabular}{l||r|r|r|r|r|r|r}
\hline \hline & N0 & N1 & \multicolumn{2}{|l|}{ N2 } & N3 & 計 \\
\cline { 3 - 6 } & & & N2a & N2b & N2c & & \\
\hline T1 & 0 & 0 & 0 & 0 & 0 & 0 & 0 \\
\hline T2 & 4 & 2 & 0 & 2 & 1 & 0 & 9 \\
\hline T3 & 3 & 3 & 3 & 4 & 4 & 1 & 18 \\
\hline T4 & 2 & 3 & 0 & 5 & 3 & 2 & 15 \\
\hline 計 & 9 & 8 & 3 & 11 & 8 & 3 & 42
\end{tabular}

表 3 胸部食道癌の合併の有無と再建方法

\begin{tabular}{|c|c|c|c|c|}
\hline \multirow[t]{2}{*}{ 再建方法 } & \multicolumn{3}{|c|}{ 胸部食道癌合併 } & \multirow[t]{2}{*}{ 胸部食道癌の治療 } \\
\hline & 有り & 無し & & \\
\hline 葹離空腸 & 3 & 33 & 36 & レーザー切除 \\
\hline 胃管十遊離空腸 & 6 & 0 & 6 & 食道抜去 \\
\hline 計 & 9 & 33 & 42 & \\
\hline
\end{tabular}


（1）全症例について,

(2) T別,

（3）部位別,

(4) 頸部リンパ節転移の有無別,

（5）術後照射の有無別,

（6）胸部食道癌合併の有無別に生存率を計算した。 生存率の差の検定には logrank 法を用いた。

2 ）死因の分析

1994年 4 月までに死亡した症例について，死因を原発 单死, リンパ節死, 遠隔転移死, 手術死, 合併症死に分

類し，手術から死亡までの日数を調べた。

3 ) 合併症

（1）術直後の合併症を調べた.

（2）摂食開始後(晚発性)の合併症を調べた.

4 ）摂食状況

再建手術後何日で経口摂取可能となったかを調べた。

更に，摂取食物を普通食，粥食，流動食，経口摂取不能 に分類し，摂取開始後の摂取内容の変化を経時的に追跡 した。

\section{結果}

1 ) 生存率の算出(表 4,5 )

(1) 全症例

全症例の 3 年生存率は $58.9 \%$ であった。ちなみに, 他 病死を打ち切りとしない場合の 3 年生存率は $52.1 \%$ であ った.

(2) $T$ 別

T別では， 3 年生存率は T2 が51.9\%, T3 が72.8\%, T4 が $49.2 \% て ゙ ，$ 生存率はT3 で最も良好であったが，
検定ではT別による生存率間に有意差は認められなかっ た。

(3) 部位別

部位別では， 3 年生存率は輪状後部で $40.0 \%$, 梨状陥 凹で58.4\%であった。咽頭後壁では全員生存中であるが 術後 3 年以上経過したものは括らず，2 年生存率は 100 $\%, 3$ 年生存率は計算不能であった。部位別でも生存率 に有意差は認められなかった。

（4）転移の有無別

頸部リンパ節転移の有無別では，転移なしでは $44.4 \%$, 転移陽性例では61.8\%で，生存率は $1 \%$ の危険率で転移 陽性例で良好であった。

（5）術後照射の有無別

術後照射の有無では，照射を行なった 30 例の 3 年生存 率は71.6\%であったが，照射を行なわなかった11例では

表 5 生存率 (2)

\begin{tabular}{|c|c|c|c|c|c|}
\hline & \multicolumn{2}{|l|}{ 照射 } & \multicolumn{2}{|c|}{ 食道痹合併 } \\
\hline & & 術後 & \begin{tabular}{|l} 
無し \\
\end{tabular} & 有り & 無し \\
\hline \multicolumn{2}{|l|}{$N$} & 30 & 11 & 9 & 33 \\
\hline \multirow[t]{3}{*}{ 生存率 } & 1 年 & 71.6 & 26.0 & 77.8 & 60.0 \\
\hline & 2 年 & 71.6 & 26.0 & ----- & 60.0 \\
\hline & 3 年 & 71.6 & 26.0 & ----- & 60.0 \\
\hline \multirow[t]{6}{*}{ 死亡数 } & 原発巣死 & 0 & 1 & 0 & $\overline{1}$ \\
\hline & リンパ節死 & 3 & 0 & 0 & 3 \\
\hline & 遠隔転移死 & 4 & 3 & 0 & 7 \\
\hline & 手術死 & 0 & 1 & 1 & 0 \\
\hline & 合併症死 & 0 & 2 & 1 & 1 \\
\hline & 他病死 & 2 & 1 & 0 & 3 \\
\hline
\end{tabular}

表 4 生存率 (1)

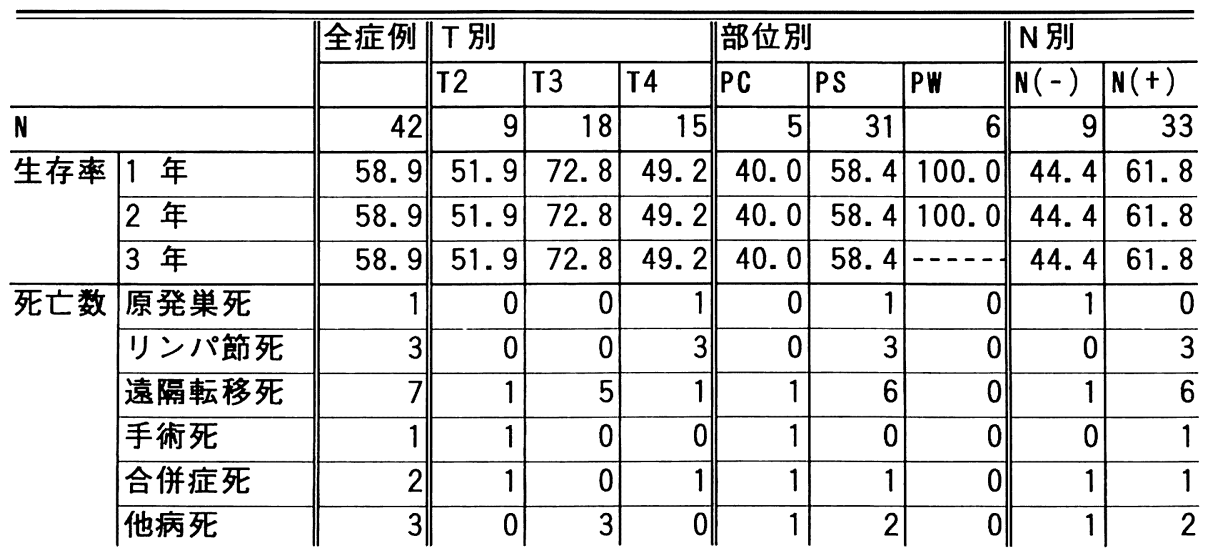


$26.0 \%$ であり $1 \%$ の危険率で有意差を認めた。またこの 11例のらち, 手術死, 合併症死した 3 名を除いた 8 名の 3 年生存率は $35.1 \%$ で，やはり $1 \%$ の危険率で有意であ った。ささらに肺転移が見つかり術後照射を行なわなかっ た 2 例を除く 6 名(拒否 1 例, 結核 1 例, 体力改善を待 つ 4 例)では， 3 年生存率は $53.3 \%$ で $5 \%$ の危険率で照 射例との間で有意差を認めた

（6）胸部食道癌合併の有無別

胸部食道癌合併例では 3 年以上経過したものはいない ため 3 年生存率は計算不能であり, 胸部食道癌の非合併 例では 3 年生存率は $60 \%$ であったが，生存率間に有意差 は認めなかった。

2 ) 死因の解析 (表 6 )

原発巣死が 1 例あり, 口側の切除断端からの再発で術 後20カ月後に死亡した.

リンパ節死は 3 例あり， 2 例はルビェール・リンパ節 からの再発 (それぞれ術後 5 力月後，14力月後に死亡)，

1 例は上絽隔リンパ節の再発 (術後20力月後に死亡)であ った。これら 3 例は術後照射を行なった後の再発である. なお，上咽頭への放射線治療後にもかかわらずルビェー ルからの再発を認める担癌生存中症例が 1 例いる。 また， 他に 1 例で上縦隔とルビェールとの同時再発があり担癌 生存中であるが，これは術後放射線治療拒否例である.

遠隔転移死は全部で 7 例あり，そのうち肺転移は 5 例 で術後 6 力月後に 2 人が死亡し， $14 ， 15 ， 50$ 力月後それ ぞれ 1 人ずつ死亡した。 また，骨転移が 1 例で，術後 4 カ月後に死亡し，肺と骨の両方に転移が認められた 1 例 は術後19力月後に死亡した.

他病死は肺炎が 2 例括り，それぞれ 4 力月後，18力月
表 6 死 因

\begin{tabular}{l|c|l}
\hline \hline & 症例数 & 再発部位、死因など \\
\hline \multirow{2}{*}{ 原発巣死 } & 1 & 口側断端からの再発 \\
\hline \multirow{2}{*}{ 遠隔転移死 } & 2 & ルビエール \\
\cline { 2 - 3 } & 1 & 上縦隔 \\
\cline { 2 - 3 } & 5 & 肺 \\
\cline { 2 - 3 } & 1 & 骨 \\
\cline { 2 - 3 } & 1 & 肺、骨 \\
\hline \multirow{2}{*}{ 他病死 } & 2 & 肺炎 \\
\cline { 2 - 3 } & 1 & 髄膜炎 \\
\hline \multirow{2}{*}{ 合併症死 } & 1 & 腎不全 \\
\cline { 2 - 3 } & 1 & 肺炎 \\
\hline 手術死 & 1 & 堅不全 \\
\hline 計 & 17 &
\end{tabular}

後に死亡した．また，䯣膜炎が 1 例で術後 12 力月後に死 亡した。

さらに，腎不全で術後 1 カ月以内に 1 例が死亡し(手 術死), 肺炎, 腎不全で 2 例が術後 2 カ月後に死亡した(合 併症死).

3 ) 合併症(表 7 )

(1) 術直後の合併症

気管口周囲の死腔のために膿瘍を形成したものが 5 例 あり，4 例では保存的治療(切開排膿など) で治癒したが, 1 例では気管形成術を要した。側吻合部で瘦孔形成し たものが 3 例あり， 2 例は保存的治療で閉鎖したが， 1 例では局所皮弁による閉鎖術を要した．肛側吻合部での 瘦孔形成は 2 例で， 1 例は局所皮弁で閉鎖したが，他の 1 例は保存的加療中に肺炎で死亡した(合併症死).

遊離空腸の全壊死は 2 例あり，共に手術翌日に壊死と

表 7 再建後の合併症

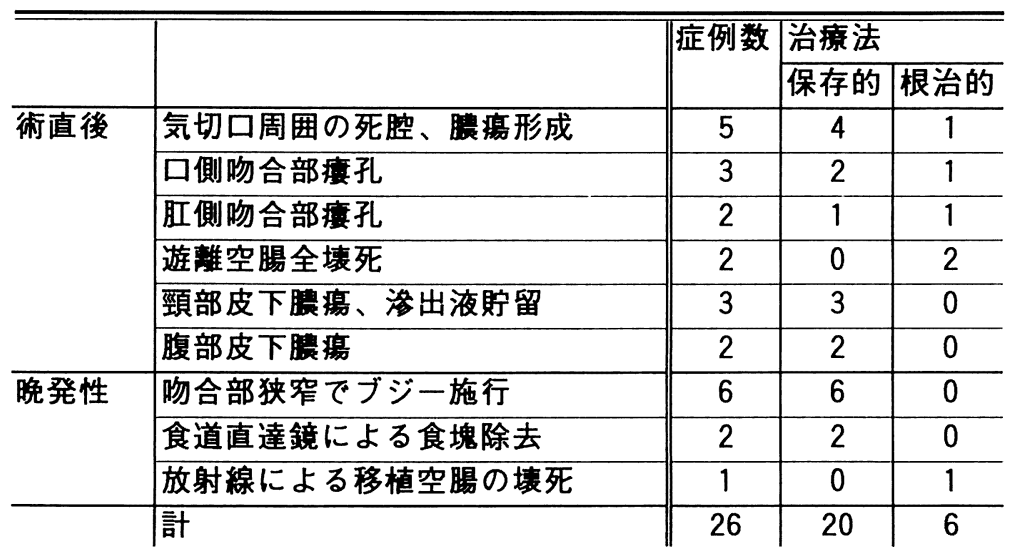


判断した時点で壊死組織を除去し，一期的再建は行なわ ずに咽頭瘦孔を形成した。 この 2 例のらち 1 例は大胸筋 皮弁で後日再建した．も51例は，大胸筋皮弁による再 建を試みたがこれも壊死し，さらに広背筋皮弁による再 建も壊死し, 現時点で, 全身状態悪化のため再建のめど はたっていない。

他に頸部皮下膿瘍や滲出液の貯留をきたした例が 3 例, 空腸採取後の腹部の皮下膿瘍形成例が 2 例認められたが, 全例切開排膿で治瘉した。

胃管についての合併症は認めていない，

なお，これらの合併症に同一症例での重複はない，

（2）摂食開始後の晚発性合併症

経口摂取開始後には, 肛側吻合部での狭窄による通過 障害に対して鯨骨ブジーによる開大を行なった例が 6 例 あった。これら 6 例は以後もブジーを頻回に行なって拈 り，そのらち 4 例は普通食の摂取は可能になって扣らず， 現在も路か流動食を摂っているが，2 例は普通食となっ た. これら 6 例以外に, 食塊が吻合部につかえて経口摂 取不能になった例が 2 例あったが，共に食道直達鏡によ り除去した。これら 2 例は普通食をその後も摂取してお り, 非担癌生存中である.

さらに，放射線によると思われる移植空腸の部分壊死 が 1 例にあり, 壊死部分の切除, DP 皮弁による被覆を 行なった，以後，摂食は普通食である。

表 8 手術直後の摂食状況

\begin{tabular}{l||c|c|c}
\hline \multicolumn{1}{c||}{ 再建方法 } & 可能 & 不可能 \\
\cline { 2 - 4 } & 症例数 & 平均日数 & 症例数 \\
\hline 胃管十遊離空腸 & 3 & 19.0 & 3 \\
\hline 遊離空腸 & 35 & 23.0 & 1 \\
\hline 計 & 38 & & 4
\end{tabular}

4 ）摂食状況

手術直後の摂食状況は表 8 の如くで，胃管釣り上げを 追加した症例では，3 例が術後平均19日後に経口摄取可 能となり，遊離空腸の久で再建した症例では術後平均 23 日後に35例で可能となった。なお，上記の瘦孔形成，空 腸全壊死症例を除くと，平均 16 日後に経口摂取可能とな った。

また, 経口摄取内容の変化は表 9 の如くで, 経口摂取 開始後半年以内では流動食, 粥食が多く, 普通食摄取可 能なのは 13 症例で，経口摂取可能症例 38 例中の $34.2 \%$ に すぎない，しかし，以後経時的に普通食摂取可能となり， 2 年半以上経過の 8 例では 7 例 (87.5\%) が普通食摂取可 能となった.

\section{考按}

1) 下咽頭癌の治療成績について

下咽頭癌の治療成績が不良であるのは言うまでもな (1) 4) が，今回の検討では 3 年生存率が約 $60 \%$ で，良 好な成績であった．下咽頭癌の手術に於て念頭におくべ きことを従来の報告からまとめると，以下の通りである。

（1）原発巣については, 腫瘍の粘膜下進展が著明なの が特徵である ${ }^{5)}$ 。咽頭側は安全域は $20 \mathrm{~mm}$ 以上1)6) であ り, 口蓋扁桃下極付近の中咽頭や切除断端からの再発が 多(、677)。また，食道側では安全域は $25 \mathrm{~mm}$ は欲しい(1)7) さらに，甲状軟骨板を通って甲状腺への浸潤がある8 で，患側の甲状腺切除が必要である5).

（2）リンパ節については， $70 \%$ の症例で患側の頸部リ ンパ節転移が認められる5)。 また，健側では $10 \%$ 30 \%77) で認められる。 そのため, N0 でも T2 以上は患側 の予防的頸部郭清が必要であり，患側に組織学的に転移 が有れば健側も郭清すべきである。また，N1 以上では

表 9 経口拱食内容の変化

\begin{tabular}{|c|c|c|c|c|c|c|}
\hline & \multicolumn{6}{|l|}{ 術後 } \\
\hline & $1-6 m$ & $-12 M$ & $-18 M$ & $-24 M$ & $-30 M$ & $31 M-$ \\
\hline 篗察症例数 & 42 & 29 & 21 & 17 & 11 & 10 \\
\hline 不明 & 0 & 5 & 7 & 2 & 2 & 2 \\
\hline 不可能 & 4 & 2 & 0 & 0 & 0 & 0 \\
\hline 流動食（（） & 4 & 1 & 1 & 1 & 0 & 0 \\
\hline 弹食 （G） & 21 & 10 & 5 & 5 & 2 & 1 \\
\hline 普通食（N） & 13 & 11 & 8 & 9 & 7 & 7 \\
\hline $\bar{N} /(L+G+N)$ & 34.2 & 50.0 & 57.1 & 60.0 & 77.8 & 87.5 \\
\hline
\end{tabular}


両側の郭清を行ならべきである1)。また，傍気管リンパ 節や靧下リンパ節 6 , 縦隔内リンパ節, ルビェール・リ ソパ節7)への転移に注意しなければならない。

（3） $10 \%$ ほどに重複癌が認められ，胸部食道癌が最も 多( 3 ).

以上の観点から咽啹食摘と遊離空腸による一期的再建 を見直すと，(1)については，まず，上方の切除端は扁 桃上極あたりで行ならことができる．いくら上方であっ ても, 遊離空腸移植であるから再建が可能である. 事実, 硬口蓋よりも上方のレベルで切除した例もある．逆に下 方は，食道を術前に精査しているので，胸部食道癌を合 併していなければ，必要なだけ下方で切除することがで きる、すなわち，上方，下方とも安全域は必要なだけと れる.

当院の1960年代の治療報告では, 原発巣死が全症例の 約 $1 / 4$ を占めていた が，今回の検討では，切除断端か らの再発，原発巣死は 1 例の久で，局所コントロールは 十分にできているといえる。

（2）については，注ぼすべての例(42例中40例)で両側 の頸部郭清を施行しており，また上頸部郭清も行なって, 靧下リンパ節も一塊として摘出している. 甲状腺切除の 後，傍気管リンパ節郭清も追加している．上方では，上 述の通り扁桃上極あたりで切断するため，ルビェール． リンパ節の触診摘出も比較的容易である．術前に縦隔内 リンパ節の腫脹の有無を確認しているから，腫脹があれ ば摘出している．さらに上縦隔とルビェールとに術後照 射を追加する，といらように，リンパ節転移には二重三 重の対策を講じているわけである. 事実, 術後照射の有 無で生存率は有意に異なっていた。

当院の遊離空腸施行前の1960年代の治療集計では, リ ンパ節死が全症例の $1 / 5$ となっている9)ことにくらべて, 絽隔リンパ節死 1 例とルビェール・リンパ節死 2 例だけ であったのは，本術式の妥当性を示すものである．しか し，これだけの予防線を張ってもリンパ節死がこれら 3 例扣り，またルビェール・リンパ節転移を認める担癌生 存中症例が 2 例いるので, リンパ節転移を如何にコント ロールするかが今後の検討課題である.

（3）の重複癌では，42例中 9 例に胸部食道癌を合併し ていたことからもわかると扮り, 重要な問題である。食 道外科が術前から胸部食道を十分チェックする必要性が 裏付けられたと考えられる。

以上のことより，成績のもっとも悪いとされる T4 で
も 3 年生存率 $49 \%$ と良好な成績を挙げることができた。 残された問題は遠隔転移死が 7 例おり，肺，骨に転移し ている点である．この転移をいかにコントロールするか も今後の問題である.

2 ）遊離空腸移植について

遊離空腸による咽喉食摘後の再建術10) はすでにその 安全性, 確実性は確認され, 有効な術式として確立され た感がある.

今回の検討では, 瘦孔形成が 5 例 $(12 \%)$, 気管口周囲 の膿瘍形成が 5 例(12\%)あったが，肺炎で死亡した 1 例 を除き，ともに保存的治療あるいは小手術により軽快し ており，以後の経過に問題はなかった。これらは遊離空 腸の血行障害や壊死に起因するものではない111. 気切口 周囲膿瘍は, 手術時に腸間膜で気管周囲をできるだけ充 填して死腔を形成しないようにすることにより，最近で は生じていない。

重篤な合併症としては, 手術死合併症死が計 3 名 ( 7 $\%$ ), 空腸全壊死 2 例 ( $5 \%$ )が挙げられる. 死亡の直接 原因は腎不全, 肝不全, 肺炎であり, 術後管理に細心の 注意が必要であることを示唆する．また，全壊死の場合 は発見次第除去することが肝要で, さもなければ頸動脈 の破裂を若起する1213)。咽頭瘦孔を作成した後, 二期的 に皮弁で再建寸ることで 1 例は回復させることができた． 放射線による空腸の壊死は 1 例だけであるが，我々の 治療方針では, リンパ節の皮膜外浸潤がある場合には頸 部にも照射するので，照射線量と部位の検討も必要であ る.

吻合部の狭窄は 7 ～12\%で見られる11) と報告されて いるが，我々の症例では 6 例(14\%)で，やや多い，4例 はブジーによる拡張で順調であるが，2 例はいまだ普通 食の摂取が困難である、吻合部の狭窄をいかに減らすか が問題である. それでも，2 年半以上生存している症例 では，8例中 7 例で特に通過障害もなく経口摄取してお り, 経時的に吻合部狭窄は問題とならなくなるものと考 えている.

燕下障害は DP 皮弁や大胸筋皮弁による再建法よりは 軽度とされ(1), 経口摂取開始までに要する日数は, 本症 例では順調に経過すれば16日であった。過去の報 告11)1314) と大差はなく, 術後早期に放射線治療を開始 できるといら点でも有利である. 


$$
\text { まとめ }
$$

1) チーム・アプローチによる咽喉食摘と遊離空腸に よる一期的再建を行なった下咽頭癌42症例について術後 の経過，合併症，摂食状況を retrospective に調べた。

2 ） 3 年生存率は $58.9 \%$ であり，良好な成績が得られ た. T別, 部位別では, 生存率に有意差は認められなか ったが，頸部リンパ節転移では転移陽性例で生存率は良 好であった。 また, 術後照射の有無では, 照射した方が 良好な生存率を得た。本術式は，局所のコントロールは 十分であるが，リンパ節転移や遠隔転移について改良の 余地があると思われた。

3 ）瘦孔形成が 5 例 (12\%), 気管口周囲の膿瘍形成が 5 例 (12\%), 手術死合併症死が計 3 名 (7\%), 空腸全壊 死 2 例 ( $5 \%$ )が認められた。 また，吻合部の狭窄は 6 例 (14\%) と，やや多いが，経時的に吻合部狭窄は問題とな らなくなるものと考えられた．経口摂取開始までに要す る日数は16日で, 術後早期に放射線治療を開始できると いう点でも有利と考兄られた。

\section{文 献}

1 ）田中信三, 平野 実, 松岡秀隆, 他 : 下咽頭癌の治療 一 20 年 間173例の検討一. 日気食会報 $43: 88 \sim 95,1992$.

2) Hirano M, Kurita S, Kuratomi K, et al : Carcinoma of the hypopharynx and cervical esophagus. Kurume Med J 29 Suppl : 97〜111, 1982.

3 ) 宮原 裕, 鶴田至宏, 馬場克則, 他: 下咽頭 - 頸部食道癌 の実態と治療(第 2 報). 日気食会報 $37: 437 \sim 455,1986$.

4 ）鳥山 稔, 上野則之, 国崎恵美子, 他 : 下咽頭 - 頸部食道
癌の臨床的研究. 耳鼻 $31: 13 \sim 19,1985$.

5 ）吉田淳一：下咽頭癌に打ける喉頭保存. JOHNS $6: 863$ 868,1990 .

6 ）廣戸幾一郎, 三橋重信, 市川昭則, 他 : 下咽頭頸部食道癌 の手術的療法. 耳鼻 $16: 156 \sim 163,1970$.

7 ）村上 泰, 猪狩武詔, 原口茂徳, 他：下咽頭頸部食道癌の 切除, 再建 1 一頸部郭清を含む切除手術一. 日気食会報 $36: 182 \sim 183,1985$.

8 ) Olofsson J and vanNostrand AWP : Growth and spread of laryngeal and hypopharyngeal carcinoma with reflections on the effect of preoperative irradiation ; 139 cases studied by whole organ serial sectioning. Acta Otolaryngol Suppl (Stockh) $308: 1 \sim 84,1973$.

9 ) 平野 実, 進 武幹, 三橋重信, 他：教室に扰ける下咽頭 頸部食道癌の遠隔成績. 耳鼻 $22: 737 \sim 747,1976$.

10) Seidenberg B, Rosenak SS, Hurwitt ES, et al : Immediate reconstruction of the cervical esophagus by a revascularized isolated jejunal segment. Ann Surg $149:$ 162 171, 1959.

11）田中信三, 平野 実, 松岡秀隆, 他 : 遊離空腸による下咽 頭, 頸部食道の再建. 日耳鼾会報 $94: 192 \sim 197,1991$.

12）竹生田勝次：下咽頭癌に扮ける再建手技とその選択. JOHNS $6: 875 \sim 881,1990$.

13) Coleman III JJ : Jejunal free autograft ; analysis of complications and their resolution. Plast Reconstr Surg 84 : 586 595, 1989.

14) Farbian RL : Reconstruction of the laryngopharynx and cervical esophagus. Laryngoscope $94: 1334 \sim 1350,1984$.

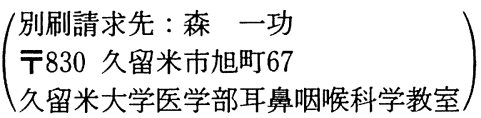

